\title{
Correction to: Rules of Conduct for Behavior Analysts in the Presence of Hypothetical Constructs: A Commentary on Eckard and Lattal (2020)
}

\author{
Armando Machado $^{1}$ (D) Paulo Guilhardi ${ }^{2}$ - Marcelo S. Caetano ${ }^{3}$. \\ Francisco J. Silva ${ }^{4}$
}

Accepted: 25 November 2020 / Published online: 10 December 2020

(C) Association for Behavior Analysis International 2020

\section{Correction to: Perspect Behav Sci https://doi.org/10.1007/s40614-020-00272-w}

The acknowledgement section was updated in the original article to include the sentence "PG would like to thank Dr. Robert F. Littleton for his ongoing support".

Publisher's Note Springer Nature remains neutral with regard to jurisdictional claims in published maps and institutional affiliations.

The online version of the original article can be found at https://doi.org/10.1007/s40614-020-00272-w

Armando Machado

armandom@ua.pt

1 University of Aveiro, Aveiro, Portugal

2 Beacon ABA Services, Inc., Leominster, MA, USA

3 Universidade Federal do ABC (UFABC), Santo André, Brazil

4 University of Redlands, Redlands, CA, USA 